\title{
Magiczna Warszawa. Fantastyczne przestrzenie polskiej stolicy w literaturze dziecięcej i młodzieżowej - wybrane przykłady
}

\section{Abstrakt:}

Artykuł zawiera analizę obrazu Warszawy w wybranych polskojęzycznych utworach fantastycznych dla dzieci i młodzieży. Autorka omawia m.in. Tajemnice Łazienek Zuzanny Rabskiej (1920), A gdzie ja się, biedniuteńki, podzieję? Joanny Papuzińskiej (1972), Felixa, Neta i Nikę oraz Pułapkę Nieśmiertelności Rafała Kosika (2009), Omege oraz Klątwe dziewiątych urodzin Marcina Szczygielskiego (2009, 2019). Podejmuje próbę wskazania, które miejsca na mapie stolicy najczęściej pojawiają się w tych utworach oraz jakimi narzędziami i zabiegami posługują się autorzy omawianych tekstów, by ukazać przestrzeń Warszawy jako magiczną oraz „ufantastycznioną”.

\section{Słowa kluczowe:}

Joanna Papuzińska, literatura fantastyczna, literatura dziecięca i młodzieżowa, Marcin Szczygielski, miasto, Rafał Kosik, przestrzeń, Warszawa, Zuzanna Rabska

\section{Magical Warsaw: Fantastic Spaces of the Polish Capital in} Children's and Young Adult Literature - Selected Examples

\section{Abstract:}

The article contains an analysis of the image of Warsaw in selected Polish-language fantasy and science fiction works for children and young adults. The author dis-

* Marta Niewieczerzał - mgr, przygotowuje rozprawę doktorską w Instytucie Literatury Polskiej Wydziału Polonistyki na Uniwersytecie Warszawskim dotyczącą obrazu Warszawy w fantastyce dziecięcej i młodzieżowej. Pracuje w Muzeum Książki Dziecięcej (dziale specjalnym i czytelni naukowej Biblioteki Publicznej m.st. Warszawy - Biblioteki Głównej Województwa Mazowieckiego). Kontakt: marta.niewieczerzal@gmail.com.

1 Artykuł powstał na podstawie referatu wygłoszonego podczas XXIX Sesji Varsavianistycznej Warszawa w kulturze dla dzieci i młodzieży, sfinansowanego ze środków Biblioteki Publicznej m.st. Warszawy - Biblioteki Głównej Województwa Mazowieckiego. 
cusses, among others, such books as Tajemnice Łazienek [The Secrets of Łazienki] by Zuzanna Rabska (1920), A gdzie ja się, biedniuteńki, podzieję? [Where Am I Going to Go, Poor Thing?] by Joanna Papuzińska (1972), Felix, Net i Nika oraz Pułapka Nieśmiertelności [Felix, Net \& Nika and the Trap of Immortality] by Rafał Kosik (2007), Omega and Klatwa dziewiatych urodzin [The Curse of the Ninth Birthday] by Marcin Szczygielski $(2009,2019)$. She attempts to indicate which places on the map of the Polish capital appear in these works the most frequently and what tools and tricks the authors of the discussed texts use to show the space of Warsaw as magical and fantasy-like.

Key words:

Joanna Papuzińska, fantasy and science fiction, children's and young adult literature, Marcin Szczygielski, city, Rafał Kosik, space, Warsaw, Zuzanna Rabska

A kcja wielu utworów beletrystycznych osadzana jest $\mathrm{w}$ przestrzeniach miast prawdziwych - np. Paryża, Londynu czy Nowego Jorku. Literackie wizerunki realnie istniejących metropolii mniej lub bardziej wiernie oddają rzeczywistość, zarazem często są uzupełniane o elementy fikcyjne, a niekiedy także fantastyczne. W Polsce duże ośrodki miejskie (m.in. Kraków, Toruń czy Warszawa) doczekały się licznych publikacji włączonych w ciąg narracji narodowych (Skotnicka, 2008; Wróblewska, 2016). Pokaźna jest zwłaszcza liczba utworów - skierowanych zarówno do dzieci oraz młodzieży, jak i do dorosłych - dotyczących Warszawy, jej przestrzeni czy społeczności, co niewątpliwie wynika z pełnienia przez gród funkcji stolicy i z jego znaczenia na mapie Polski.

Elżbieta Rybicka (2014) we wstępie do książki Geopoetyka. Przestrzeń i miejsce we wspótczesnych teoriach $i$ praktykach literackich zwraca uwagę na otwarty charakter obszaru problemowego tytułowej dziedziny, w którym możemy wszak wyróżnić takie zjawiska jak „mapy, miejsca, toponimy literackie, geografie wyobrażone, imagologie terytorialne, lieux d'imagination, literacka geografia sensoryczna, geografia emocji, związek autobiografii i geografii, literackie miejsca pamięci, nowy regionalizm" (s. 9). Jak jednak słusznie zaznacza Krzysztof M. Maj (2018), w Polsce w głównym nurcie badań nad topografią literacką i geopoetyką często pomija się fantastykę, w tym - dziecięcą i młodzieżową ${ }^{2}$. Istnieje wiele utworów dla dorosłych odbiorców, w których miasto pełni

2 Ten brak częściowo wypełnia tom zbiorowy Geografia krain zmyślonych. Wokół kategorii miejsca i przestrzeni w literaturze dziecięcej, młodzieżowej i fantastycznej pod redakcją Weroniki Kosteckiej i Macieja Skowery (2016). Warto wspomnieć również, że monografię poświęcono Krakowowi w literaturze dla młodych czytelników (Kraków mityczny. Motywy, wątki, obrazy w utworach dla dzieci i młodzieży pod redakcją Alicji Baluch, Małgorzaty Chrobak i Michała Rogoża, 2009). 
ważną funkcję oraz jest kluczowe dla narracji ${ }^{3}$, natomiast na ogół uznaje się, że w tekstach skierowanych do dzieci i młodzieży przestrzeń miejska pozostaje niezbyt eksponowanym tłem dla rozgrywających się wydarzeń oraz w niewielkim stopniu wpływa na działania bohaterów (Wróblewska, 2016, s. 79). W takich dziełach pojawiają się przede wszystkim tzw. miejsca mocne, tj. punkty, które wydają się najbardziej znane, a $\mathrm{z}$ tego powodu są najczęściej celem np. szkolnych i rodzinnych wycieczek (s. 80). Dziecięca i młodzieżowa literatura fantastyczna, będąca przedmiotem rozważań w niniejszym artykule, eksponuje nie tylko, co oczywiste, popularne miejsca, lecz także pozwala ukazać, jak przestrzeń Warszawy przechodzi liczne transformacje i wskutek szeregu różnych zabiegów jawi się jako magiczna i tajemnicza, należąca nie tylko do świata realnego. Co istotne, jak stwierdza Anna Mik (2016): „Prawdopodobieństwo istnienia fikcyjnego świata nie tylko daje podwaliny pod czytelniczy eskapizm, lecz także wprowadza do świata faktycznego pierwiastek niezwykłości, zaczarowując tym samym szarą rzeczywistość" (s. 99). Nasycanie empirycznej przestrzeni Warszawy elementami fantastycznymi ma zatem na celu zarówno uatrakcyjnienie lektury, jak i zasugerowanie czytelnikowi możliwości istnienia wspomnianego „pierwiastka niezwykłości” oraz wskazanie na współzależność różnych przestrzeni - tych realnych i tych magicznych.

Paweł Dunin-Wąsowicz (2010) jako autor Warszawy fantastycznej, szczególnego kompendium varsavianistycznej wiedzy, zauważa, że: „Fantastyczny potencjał miasta nie jest związany z liczbą mieszkańców[,] lecz z jego kulturową pozycją, na którą składa się stołeczność [...] oraz historia - w przypadku Warszawy wyjątkowo bolesna w latach II wojny światowej” (s. 10) ${ }^{4}$. Badacz

3 Na gruncie polskim to np. Lalka Bolesława Prusa (1890), Ziemia obiecana Władysława Reymonta (1899) czy Zły Leopolda Tyrmanda (1955). Fenomen miasta i miejskości w literaturze to niezwykle obszerne zagadnienie, łączące wiele zjawisk i znaczeń, które są rozwijane przez autorów i omawiane pod różnym kątem w licznych opracowaniach, takich jak Warszawa pozytywistów pod redakcją Joanny Kulczyckiej-Saloni oraz Ewy Ihnatowicz (1993) czy Modernizowanie miasta. Zarys problematyki urbanistycznej w nowoczesnej literaturze polskiej Rybickiej (2003). Niewątpliwie w porównaniu do literatury dla dorosłych teksty skierowane do młodszych odbiorców niekiedy upraszczają i częściowo infantylizują obraz Warszawy, a autorzy, przedstawiając miejsce akcji, starają się w jak najprostszy sposób przekazać czytelnikowi najważniejsze informacje.

4 Historia, o której wspomina autor, pozostaje ważnym elementem tekstów skierowanych do młodych odbiorców i pozwala na kreowanie rozmaitych utworów, nie tylko tych o charakterze ściśle dydaktycznym. Wokół postaci oraz wydarzeń istotnych dla Warszawy osnute są często opowieści mające na celu ugruntowanie ich w zbiorowej pamięci, stąd też akcja takich dzieł toczy się zazwyczaj w miejscach i przestrzeniach charakterystycznych dla konkretnych figur oraz doniosłych epizodów z dziejów stolicy (jak utwory o II wojnie 
na potrzeby przywołanej publikacji wprowadza podział odnoszących się do stolicy tekstów, które wykraczają poza poetykę realistyczną: pierwsza grupa zawiera historie „dziejące się w przyszłości, dla której odniesieniem jest rzeczywistość współczesna pisarzom"; kolejna - to historie alternatywne, których autorzy zakładali, że „dzieje świata [...] przybrały w czasach poprzedzających publikację ich utworów obrót odmienny od rzeczywistego", a „powieści i opowiadania $\mathrm{z}$ tej grupy zawierają wówczas projekcje następstw takich zmian historii"; trzecia obejmuje m.in. literaturę fantasy, dopuszcza istnienie światów kontrempirycznych (w tego rodzaju utworach obecne są m.in. elfy, duchy i wszelkie rodzaju potwory): „Literatura ta [...] najczęściej osadzona jest w realiach współczesnych autorom i czytelnikom, ale sięga zarówno w przyszłość[,] jak [i w] przeszłość - również w alternatywnych wersjach historii” (s. 10). Przedmiotem rozważań w niniejszym artykule są przede wszystkim utwory kwalifikujące się do ostatniej grupy wyróżnionej przez badacza, czyli takie, gdzie w miejskiej przestrzeni pojawiają się elementy fantastyczne, w tym baśniowe ${ }^{5}$. Warto zastanowić się, jak zaprezentowana zostaje przestrzeń Warszawy w tego typu dziełach skierowanych do dzieci i młodzieży, a konkretnie - w jaki sposób zurbanizowana przestrzeń wpływa na świat narracji w utworze nierealistycznym oraz które miejsca są przez autorów wykorzystywane i opisywane. Na podstawie kilku wybranych, reprezentatywnych przykładów omówię różne sposoby przedstawiania „ufantastycznionej” Warszawy, której podstawę stanowi przestrzeń realnie istniejącego miasta.

Ważnym punktem na mapie stolicy, którego liczne obrazy odnajdziemy w rodzimej literaturze dziecięcej i młodzieżowej, jest zespół pałacowo-ogrodowy założony w XVIII wieku przez Stanisława Augusta Poniatowskiego, zwany Łazienkami. Jednym $\mathrm{z}$ utworów poświęconych temu miejscu, wydanym kilka lat po wykonanym przez Zofię Rogoszównę pierwszym polskim tłumaczeniu

światowej - np. Kotka Brygidy Joanny Rudniańskiej, 2007; Arka czasu, czyli wielka ucieczka Rafała od kiedyś do wtedy przez teraz i wstecz Marcina Szczygielskiego, 2013). Współcześnie historia często wzbogacana jest o dodatkowe elementy, w wieku XX rzadziej obecne w literackich narracjach o tym mieście, a dzięki temu zarówno sama stolica, jak i jej dzieje mogą prezentować się bardziej niezwykle i odmiennie niż w dotychczas znanych utworach.

5 Teksty, „w których fantastyka i świat, w którym żyjemy, przecinają się i przeplatają, a opowieść koncentruje się na rzeczywiście istniejącym mieście" (Clute, 1999, s. 975; cyt. za: Ekman, 2016/2018, s. 13), można zaliczyć również do fantastyki miejskiej. Ta kwestia jest niezwykle obszerna i zostaje jedynie zasygnalizowana w niniejszym artykule; nie wszystkie omawiane przeze mnie teksty można też uznać stricte za utwory reprezentujące tę odmianę gatunkową. Więcej na ten temat można przeczytać w numerze Creatio Fantastica w całości poświęconym owemu zagadnieniu, zatytułowanym Fantastyka miejska (2018). 
Przygód Piotrusia Pana (Barrie, 1906/1913) i czerpiącym z niego liczne inspiracje, są Tajemnice Łazienek Zuzanny Rabskiej (1920c). Zbiór składa się z dziesięciu opowiadań z elementami fantastycznymi, a miejscem akcji w każdym z nich, jak sugeruje już tytuł, są właśnie Łazienki - do dziś pozostające znanym celem wędrówek turystów i wycieczek szkolnych. Główni bohaterowie zawartych w książce historii (przede wszystkim dzieci) dostrzegają w parku więcej niż zwykli spacerowicze. Na przykład pierwsza z opowieści, Sny Wiesi, mówi o dziewczynce, której śnią się tańce i swawole satyrów mieszkających rzekomo w Łazienkach (Rabska, 1920b). Konwencja snu, widzenia, mieszanie ułudy z rzeczywistością - pozwala na kreację fantastycznej wizji ogrodu, w którym słychać dziwne głosy, szelesty. Mieszkańcami parku są zaś niezwykłe postaci, takie jak karzełki, wróżki, a także elfy i wspomniani wyżej satyrowie. W innym z opowiadań, Choinka Marcysi, odnajdziemy z kolei echa Dziewczynki z zapałkami Hansa Christiana Andersena (1845/2005): oto sierota Marcysia przypadkiem trafia do Łazienek, gdzie wydaje jej się, że widzi wróżkę zapalającą na choince przedziwne światełka, wyglądające jak „cudowne gwiazdy, srebrne i złote” (Rabska, 1920a, s. 89). Jarzące się drzewko ma podobne właściwości do zapałek z Andersenowskiej baśni: pozwala bohaterce zobaczyć zmarłą matkę, która po chwili „rozwiewa się jak mgła” (s. 90). Jednak tutaj zakończenie historii okazuje się inne niż u duńskiego pisarza - zamarzającą protagonistkę odnajdują żołnierze i zabierają ze sobą, by się nią zaopiekować. Tym samym zostaje podkreślona cudowność Łazienek jako Arkadii, w której każdy otrzymuje szczęśliwe zakończenie.

Wspomniany park jest też miejscem akcji powieści Ania $w$ Łazienkach, również autorstwa Rabskiej (1957). Tytułowa bohaterka utworu może tam przeżywać wspaniałe przygody i spotykać fantastyczne postaci - wróżki, a nawet Syrenę, której pomaga wrócić na Starówkę. W tym przypadku również mamy do czynienia z liryczną, senną poetyką: „Pokryty grubym kożuchem śniegu park łazienkowski drzemie w oczekiwaniu ciepłych promieni słońca, pod którym stopnieją śniegi i lody. I do parku powróci znowu Przeszłość, zaklęta w pałace, drzewa i posągi” (s. 195). Łazienki w szczególny sposób pełnią funkcję strażnika pamięci i obserwatora przeszłych oraz bieżących wydarzeń, czego wyrazem jest też napotkanie przez protagonistkę nieznajomego mężczyzny w podeszłym wieku, który cały park zna ,jak własną kieszeń” (s. 17) i jawi się jako osobliwy przewodnik po tym terenie oraz jego opiekun. Ogród, jak biblijny Eden u swego zarania, daje poczucie harmonii i pozwala na chwilę wytchnienia, a dziecko - należące niejako do rajskiego porządku - może, w przeciwieństwie do dorosłych, komunikować się z jego mieszkańcami. Dzieci w omawianych utworach Rabskiej ukazane są jako istoty „widzące więcej” 
(lub mające widzenia), podobnie jak w tradycji romantycznej (Kubale, 1984). Same Łazienki to miejsce pełne sekretów, należące nie tylko do śmiertelników, lecz także do istot magicznych; parkiem rządzi bowiem ukryty, pierwotny porządek. Wydaje się, że przede wszystkim najmłodsi mogą tam dostrzec to, co skrywa widoczna na pierwszy rzut oka warstwa ogrodu. Marzenia senne są zatem łącznikiem świata rzeczywistego ze światem magicznym, a jednocześnie granica pomiędzy snem a jawą pozostaje płynna. Stwierdzić można z pewnością, że Łazienki jako symbol stolicy pozostają zapisane w świadomości zarówno dorosłych, jak i dzieci' ${ }^{6}$. Być może to właśnie zakorzenienie ich obrazu w zbiorowej wyobraźni oraz pamięci skutkuje transformacjami i budowaniem fantastycznych historii dziejących się za bramami parku.

Przykładem tekstu uwydatniającego zmiany zachodzące $\mathrm{w}$ przestrzeni miejskiej, a jednocześnie ukazującego ich wpływ na znane z tradycji kultury postaci, jest natomiast utwór A gdzie ja się, biedniuteńki, podzieję? Joanny Papuzińskiej (1972). Jego akcja rozpoczyna się w momencie spóźnienia się jednego z bohaterów, „taty”, na autobus. Gdy mężczyzna czeka na przystanku na kolejny, nagle z pnia wierzby wyłania się nieznana istota. Odbywają następujący dialog: „- Rokita? - krzyknął tata zdumiony [...]. To naprawdę ja, a raczej mój cień, moje nędzne resztki! - odpowiedziało licho żałośnie [...]” (s. 7). Z dalszej części rozmowy wynika, że wierzba, w której mieszkało owo stworzenie, została ścięta przez robotników budujących nową autostradę; to przez nieustającą urbanizację terenów podmiejskich i leśnych licho musi szukać nowego miejsca do zamieszkania, Jak samo mówi: „Zabieram [...] manatki i szukam innej drogi i innej wierzby!" (s. 10), ale niestety - ścięte drzewo okazuje się ostatnim w okolicy reprezentantem swojego rodzaju. Papuzińska odwołuje się do zaświadczonego w podaniach ludowych pierwotnego obrazu Rokity jako ducha leśnego, dopiero z czasem, w późniejszych tekstach, zamienionego w diabła. Imię tej istoty (co znaczące, autorka w tekście używa również zdrobniałej formy - Rokiś) pochodzi od zwyczaju przebywania w lasach, rokitach, łozach i suchych wierzbach (Rzepnikowska, 2016-2018), dlatego też miasto, a szczególnie powstałe w nim zakłady przemysłowe i budowlane, jawią się Rokicie jako coś strasznego, nieznanego:

6 W literaturze można odnaleźć wiele przykładów prostych, rymowanych wierszy dla najmłodszych, gdzie ukazuje się Łazienki - zob. m.in tytułowy utwór z tomu Na przykład Ogród Saski Adama Międzyrzeckiego (1965): „Tak jak się zna swoje imię / i palce własnej ręki / tak każdy znać powinien / Warszawski park Łazienki” (s. [11]). Nieskomplikowana, rymowana forma pokazuje głębokie zakorzenienie tego miejsca w rodzimej świadomości. 
Na tle ciemniejącego już od wschodu nieba widać było kontury budynków oraz wielkich pękatych zbiorników, podobnych do beczek z kapustą w spiżarni u wielkoluda. Między beczkami, niczym fantastyczne słoniowe trąby, unosiły się powyginane dziwaczne rury, łączące zbiorniki ze sobą. Cały ten niesamowity krajobraz oświetlały chwiejące się na wietrze płomienie u szczytu cienkich i wysokich kominów (Papuzińska, 1972, s. 12).

„Kombinat”, o którym czytamy, „pożre wszystkie spróchniałe wierzby i wszystkie wsie, i lasy, i dzikie zwierzęta, i wszystkich diabłów takich jak ja!" (Papuzińska, 1972, s. 12) - mówi Rokiś. Wydaje się, że w nowoczesnym mieście, w zurbanizowanej przestrzeni, nie ma miejsca na tajemnicze istoty, a szczególnie na straszliwe stwory. Jak bowiem zauważa Rokita: „Tylko biedny diabeł nie ma się gdzie podziać i nikt się nim nie zajmie! Krasnoludki, wróżki, duszki [...]! Nad tymi wszyscy się rozczulają! Dla nich są książeczki, obrazeczki, bajeczki, one rozpierają się na wszystkich ścianach przedszkoli i dziecińców!” (również s. 12). Być może infantylizująca zmiana imienia z „Rokity” na "Rokisia”, a raczej - utworzenie deminutywu, to próba oswojenia tego demona, który w opowiadaniach ludowych był przecież niebezpieczny, a z czasem został skojarzony z największym złem ${ }^{7}$. U Papuzińskiej jest to natomiast biedne i pokrzywdzone licho wierzbowe, które potrzebuje schronienia i znajduje je w ludzkim domu. Tradycyjny wzorzec zakorzeniony w wyobraźni hipotetycznych odbiorców zostaje zanegowany, a demon - pozbawiony swych charakterystycznych cech (zmiany w przestrzeni związane z postępem cywilizacyjnym dotykają skądinąd wszelkiego typu stworów, lich i innych fantastycznych postaci należących do niematerialnej tkanki Warszawy ${ }^{8}$ ). Rokita, który zamieszkiwał tereny wiejskie, musi pogodzić się z tym, że jego wieś staje się miastem, a „wąska szosa” przerabiana jest na dwupasmową autostradę. Elementem potencjalnie odbierającym czytelnikom bezpieczeństwo i wzbudzającym grozę

7 Do ukazywania Rokity jak groźnego diabła powrócą m.in. twórcy projektu Legendy Polskie. Allegro w jednym z filmów krótkometrażowych, noszącym tytuł Operacja Bazyliszek (Bagiński, 2016).

8 W wielu utworach omawianych w dalszej częsci tego artykułu Warszawa to miejsce przenikania się przeszłości i teraźniejszości, co uwidacznia się także w portretach niezwykłych postaci, które zamieszkują stolicę. W tym kontekście wspomnieć można też krótko o nieomawianym przeze mnie szczegółowo - wierszowanym utworze Malowana awantura Marii Terlikowskiej (1970), w którym postaci ze starych obrazów przenoszą się do czasów współczesnych; nie są to jednak bohaterowie baśni czy legend, lecz Rzymianin, Rycerz i dwie Damy (każda z innej epoki). Są zdziwieni tym, jak wygląda XX-wieczny świat; przeczuwają, że do niego nie pasują, więc, odprowadzeni przez uczniów, wracają do ram obrazu i tym samym kończy się ich przygoda. 
nie jest w utworze Papuzińskiej demon z opowiadań ludowych, lecz budujące się, antropomorfizowane miasto - potwór pochłaniający kolejne tereny leżące w jego zasięgu.

Wart uwagi jest również wydawany od 2004 roku cykl powieściowy Felix, Net i Nika autorstwa Rafała Kosika. Według Dunina-Wąsowicza (2010, s. 125) właśnie ten pisarz ma największe zasługi dla stołecznej urban fantasy. Autor Warszawy fantastycznej zaczerpnął z wywiadu z Kosikiem, przeprowadzonego przez Łukasza Orbitowskiego i Jarosława Urbaniuka (2008), ciekawe i trafne określenie, które stosuje dla opisu przestrzeni miasta w analizowanym cyklu: „Warszawa Plus”. W jej skład wchodzi, oprócz tego, co widać „na powierzchni”, również tzw. Podwarszawa ${ }^{9}$, w której mieszkają przedziwne istoty - uciekinierzy od cywilizacji - oraz gdzie znajdują się liczne place i budowle, a nawet labirynty:

Niespodzianie [bohaterowie] znaleźli się na sporej przestrzeni. Odwrócili się za siebie i ujrzeli kilkupiętrową kamienicę, której brama była wylotem tunelu. Znajdowali się na ulicy, wzdłuż której wznosiły się rzędy pozbawionych szyb kamienic. Tak mogła wyglądać dawno temu Warszawa. Tylko, że tutaj zamiast nieba była szara betonowa płaszczyzna [...]. - Podmiasto - odparł Felix. - Podwarszawa. Stara Podwarszawa (Kosik, 2007/2009, s. 476-477).

Określenie „Warszawa Plus” jest bardzo szerokie i pozwala spojrzeć na przestrzeń stolicy nie tylko w perspektywie horyzontalnej, do czego jesteśmy przyzwyczajeni, lecz także wertykalnej. Owa przestrzeń staje się bardzo pojemna, a pojawienie się u Kosika m.in. odwołań do legend warszawskich pokazuje, jak żywa pozostaje idea powrotu do dziedzictwa podań lokalnych: w zacytowanej wyżej czwartej części cyklu, Feliksie, Necie i Nice oraz Pułapce Nieśmiertelności z 2007 roku, w Podwarszawie skrywa się poszukiwany przez wszystkich Bazyliszek. Potwór cechuje się monstrualną, nienaturalną hybrydycznością, która była jego właściwością $\mathrm{w}$ dawnych przekazach - ale w tym przypadku to nie potworny „niby kogut, niby wąż” (Oppman, 1925/1945, s. 45), lecz mechaniczne ciało z mózgiem człowieka. Robot ma trzy metry wysokości i wielkie jak łyżka koparki dłonie, a z jego „oczu” - reflektorów - wydobywa się zielone światło. Co więcej, oprócz miejsc realnie istniejących na mapie Warszawy, u Kosika pojawiają się stworzone na potrzeby powieści budowle (np. gmach Instytutu Badań Nadzwyczajnych) czy ulice, a adresy zamieszkania trójki głównych bohaterów także są fikcyjne - nierealne, ale możliwe (Dunin-Wąsowicz, 2010, s. 139). Szkoła, do której uczęszczają

9 Nazwa i sama idea Podwarszawy mogą budzić skojarzenia z Londynem Pod z powieści Nigdziebądź Neila Gaimana (1996/2001). 
protagoniści, również kryje niezbadane tajemnice (na poddaszu straszy, ponieważ zostały tam zamurowane ludzkie szczątki). W drugim tomie serii, zatytułowanym Felix, Net i Nika oraz Teoretycznie Możliwa Katastrofa (Kosik, 2005), pojawiają się zaś podróże zarówno w odległą przyszłość, jak i w przeszłość, co dowodzi przenikania się czasów, których niezmiennym elementem są warszawskie miejsca i przestrzenie (to np. Pałac Kultury i Nauki: najpierw, w 2060 roku, funkcjonuje jako podstawowy punkt orientacyjny, a w kolejnej podróży, w 2110 - po katastrofie ekologicznej, jego szczątki wystają ponad piach, który zasypał dawne miasto). „Ufantastycznianie” stolicy w całym cyklu Kosika odbywa się zatem za pomocą znanych $\mathrm{z}$ tradycji science fiction motywów fabularnych, takich jak wędrówki w czasie, ale też eksperymenty naukowe czy obecność sztucznej inteligencji (Wróblewski, 2010).

Utworami dla młodzieży, które łączą rzeczywistą historię Warszawy z elementami fantastycznymi, są natomiast m.in. niektóre z komiksów zawartych w wydawanych przez Muzeum Powstania Warszawskiego antologiach Powstanie ' 44 w komiksie (znajdują się w nich prace wyróżnione w ogólnopolskim konkursie na komiks o powstaniu warszawskim). Przykładem może być Legenda o Powstaniu Tomasza Pastuszki (2009), w której jeden z partyzantów spotyka w kanałach, charakterystycznej powstańczej przestrzeni, ukrywające się przed nazistami postaci z legend warszawskich - Bazyliszka, Syrenkę i Złotą Kaczkę. Ich kryjówka zostaje odkryta, więc Syrenka, by zatrzymać wrogów, zaczyna śpiewać hymn Polski. Można uznać to za jasne odwołanie do głosu mitologicznych syren, które swym śpiewem wabiły marynarzy, chcąc sprowadzić ich statki na mieliznę. W komiksie Pastuszki Syrenka zostaje postrzelona przez żołnierzy i w ostatnich chwilach przed śmiercią staje na postumencie, gdzie Bazyliszek (zwany Bazylim) zamienia ją w kamień, tym samym czyniąc z niej symbol i zarazem pomnik stojący w stolicy do dziś. Wykorzystanie legend warszawskich w komiksie, który nawiązuje do ważnego wydarzenia dziejowego, jest przekroczeniem pewnych granic dotyczących opowiadania historii miasta - jest to narracja inna niż ta znana z podręczników szkolnych, ale też inna niż ta z podań lokalnych. U Pastuszki bowiem postaci z legend warszawskich funkcjonują równolegle i w jednej przestrzeni z rzeczywistością historyczną, zaznaczając swoją obecność podczas istotnych wydarzeń historycznych. Dzięki grze z pierwowzorem odwrócona zostaje rola istot, które w tradycyjnych przekazach były charakteryzowane jako negatywne (zabijającego wzrokiem Bazyliszka czy złej księżniczki zaklętej w Złotą Kaczkę), w komiksie zyskują one bowiem cechy właściwe bohaterom pozytywnym.

Podobnie jawi się łączenie dwóch pozornie odległych światów w powieści Klątwa dziewiątych urodzin Marcina Szczygielskiego (2016), czyli trzeciej 
część cyklu o przygodach Mai i jej krewnych - czarownic. W powieści pojawiają się postaci z legend warszawskich, tu jednak bohaterowie ci zmieniają się i ewoluują w porównaniu do najbardziej rozpowszechnionych wariantów (np. autorstwa Romana Zmorskiego, Artura Oppmana, Wandy Chotomskiej, Ewy Szelburg-Zarembiny itp. ${ }^{10}$. Złota Kaczka to u Szczygielskiego tak naprawdę Złoty Kaczor, mieszkający, podobnie jak w tradycyjnej wersji, na Powiślu, pod zamkiem Ostrogskich. Przestrzeń miejska zmienia się i teraz mieści się tam Muzeum Chopina, a znakiem pamięci o legendzie jest jedynie stojący w pobliżu pomnik Złotej Kaczki. Podobnie dzieje się z innymi postaciami, np. Wars i Sawa prowadzą domy handlowe przy ulicy Marszałkowskiej nazwane ich imionami, a Syrenka zestarzała się i przytyła, gdyż podjada ze słoików (co jest aluzją do nazywania nowych mieszkańców miasta „słoikami” przez rodowitych warszawian). W utworze czytamy:

Na kanapie leżała okropnie gruba kobieta w średnim wieku, ubrana w poplamiony biały T-shirt z napisem „I love Warsaw”. Gęste ciemne włosy, przetkane pasmami siwizny, upięła w nieporządny kok. Zamiast nóg miała rybi ogon ozdobiony kolorowymi kapslami od butelek. Jadła kopytka ze skwarkami i oglądała Mała Syrenkę na turystycznym czarno-białym telewizorku, do którego podłączony był przedpotopowy magnetowid (s. 171).

Postaci z legend - należące, zdawałoby się, do innego niż rzeczywisty porządku - nie funkcjonują tu jako echa zapomnianych tradycji, lecz jako pełnoprawni mieszkańcy Warszawy. Oczywiście pojawiają się w kluczowych punktach na mapie, w miejscach powszechnie kojarzonych z tymi bohaterami - np. Złoty Kaczor przebywa na Tamce, a Syrena ma schronienie w wodach Wisły (choć w pobliżu symbolu współczesnej stolicy - drugiej linii metra, której budowę bohaterka ponoć sabotowała). Postmodernistyczne strategie i intertekstualne praktyki, które wykorzystuje Szczygielski, ożywiają częściowo zapomnianych protagonistów i antagonistów, pozwalają na obdarzenie ich nowym życiorysem czy na zmianę charakteru oraz wyglądu. To właśnie - bliska współczesnemu wykorzystaniu baśni - „gra z tradycją” (Kostecka, 2014) pozostaje głównym narzędziem przetwarzania przez tego twórcę zastanego stanu rzeczy i „ufantastyczniania" przestrzeni stolicy.

Wspomniany pisarz także w innych utworach pokazuje nieustanny ruch miasta. Takie spojrzenie na zurbanizowaną przestrzeń zostaje uwypuklone

10 Więcej na ten temat pisałam $\mathrm{w}$ artykule Stare $i$ nowe miasto. Przyszłość bohaterów warszawskich legend (Niewieczerzał, 2019) 
w Omedze (Szczygielski, 2009). Główna bohaterka, Joanna/Omega, na dwunaste urodziny otrzymuje zagadkowy prezent - to e-mail z linkiem do gry, która po włączeniu natychmiast zmienia świat otaczający dziewczynę. Rzeczywistość łączy się z elementami wirtualnymi, a protagonistka, przechodząc kolejne poziomy owej gry, jednocześnie przemierza kolejne obszary Warszawy (w jej zmodyfikowanej wersji). Jak zauważa Weronika Kostecka (2016):

Szczygielski nie tylko wykorzystuje przestrzeń wykreowanego przez siebie świata przedstawionego jako „tło”, scenerię opisywanych wydarzeń, lecz przede wszystkim gra tym wymiarem literackim, bawi się jego kształtowaniem, nadając przestrzeni istotne, pierwszoplanowe wręcz znaczenie (s. 337).

Każdy poziom to zupełnie inna cyfrowa, lecz jednocześnie „magiczna” przestrzeń, mająca swój odpowiednik w rzeczywistości (zazwyczaj łatwy do rozpoznania przez potencjalnego czytelnika, zwłaszcza mieszkającego w Warszawie), np. stadion, na którym odbywają się zawody, wzorowany jest na Stadionie Dziesięciolecia, a cmentarzysko, gdzie z grobów wstają zmarli, to przekształcony cmentarz Powązkowski.

W pewnym momencie dziewczyna spotyka powstańców warszawskich i kiedy z lekceważeniem upomina jednego z nich, otrzymuje od babci naganę. Dwie bohaterki różni zupełnie inne postrzeganie czasu i rzeczywistości: to, co dla jednej było świętością, dla drugiej nie ma już znaczenia. Nieuchronne przemijanie pokoleń prowadzi więc do zmian w spojrzeniu na otaczający świat. Powieści Szczygielskiego, jak widać, ożywiają przeszłość: nie tylko legendy, lecz także zapisane na kartach historii wydarzenia związane z konkretną przestrzenią (w Omedze bohaterka mierzy się bowiem m.in. z armią zombie, wśród których znajdują się ofiary Holokaustu). Jednym z symboli ponowoczesności są natomiast tzw. Filtry Czasu (odpowiednik stołecznego Zespołu Stacji Filtrów), które powstały, „aby odsiewać całą materię i myśli nieistotne, a przepuszczać jedynie ważkie wspomnienia”, jak zaś informuje tekst dalej, „ostatniemi czasy ludzie przepominają daleko więcej i znacznie prędzej niźli drzewiej” (Szczygielski, 2009, s. 522). Nie dziwi zatem, że w powieści, o czym już wspomniałam, czasy mieszają się, a poziomy gry, które przechodzi protagonistka, to kolejne „ufantastycznione” przestrzenie. Obraz stolicy jawi się zatem jako składający się z wielu mniejszych fragmentów, a w osiągnięciu takiego wrażenia pomaga zabieg umieszczenia akcji w niejednorodnej, pokawałkowanej cyberprzestrzeni. Dodatkowo Omega pokazuje, jak mocno współczesność zanurzona jest w przeszłości i jak przewrotnie kultura popularna wydobywa $\mathrm{z}$ zapomnienia pewne wątki oraz motywy. Według Kosteckiej (2016): 
[...] sama kultura popularna, w ujęciu Szczygielskiego, okazuje się przestrzenią, w której spotykają się miejsca i tematy z najróżniejszych porządków. Kultura popularna wchłania oraz na swój sposób przetwarza i przedstawia aktualne niekonieczne nowe, ale żywotne w dyskursie społecznym zagadnienia i motywy rozmaitej proweniencji (s. 348).

Warszawa wyłaniająca się z omówionych utworów Szczygielskiego również staje się poniekąd taką przestrzenią, o której pisze badaczka: łączącą niekiedy niepasujące do siebie elementy, kreującą miejsce do prowadzenia wielogłosowego dialogu.

Zaprezentowane przykłady pokazują jedynie wycinek fantastycznych przestrzeni stolicy, do których, oprócz elementów materialnych, tworzących strukturę miejską, przynależą również postaci z nimi związane. Niewątpliwie autorzy omówionych utworów starają się wzbogacić mapę Warszawy, m.in. poprzez w prowadzenie fikcyjnych adresów, nieistniejących budynków, fantastycznych bohaterów itp.; powoduje to, że „poniekąd narzucona wizja świata, w którym to, co rzeczywiste, i to, co fikcyjne, nieustannie się ze sobą miesza, skutkuje zmianą percepcji czytelnika: nie wszystko jest bowiem tym, czym się wydaje" (Mik, 2016, s. 118). Nawet postaci z legend i związane z nimi miejsca zmieniają się, przystosowując do otaczającej rzeczywistości. W mieście, jak słusznie zauważa Piotr Lorens (2014):

Sfera kulturowa przeplata się z materialną, [...] zmienia się [...] charakter [przestrzeni] w zależności od użytkowników, ich tradycji, aspiracji, światopoglądu. Geneza powstania i historia miasta[,] a także struktura społeczna i jej ewolucja[,] wpływają najsilniej na sferę kulturową, która jest swoistym kołem zamachowym rozwoju organizmu miejskiego (s. 24).

Przestrzenie Warszawy ewoluują i przechodzą liczne transformacje, a gry z tradycją literacką, które proponują twórcy omawianych tekstów, pozwalają ukazać stolicę jako miasto magiczne, pełne wciąż nie do końca zbadanych, a nawet nieodkrytych miejsc. Na pozór znane ulice, ogrody i budynki skrywają liczne sekrety oraz są schronieniem dla fantastycznych istot. Autorzy prezentują różne wizje Warszawy i jej przestrzeni, w których częściowo zapomniane opowieści oraz postaci żyją na nowo. Omówione dzieła w wielu przypadkach, co istotne i interesujące, wykorzystują tradycyjne tropy, motywy, postaci z podań lokalnych i opowiadań ludowych; reinterpretują je, konfrontując jednocześnie z nowym, zurbanizowanym światem. 


\section{Bibliografia}

Andersen, H. C. (2005). Dziewczynka z zapałkami. W: Baśnie (B. Sochańska, tłum., s. 214-217). Media Rodzina. (wyd. oryg. 1845).

Bagiński, T. (reż.). (2016). Operacja Bazyliszek [film krótkometrażowy]. Allegro.pl, Platige Image.

Baluch, A., Chrobak, M., Rogoż, M. (red.). (2009). Kraków mityczny. Motywy, wątki, obrazy w utworach dla dzieci i młodzieży. WN UP.

Barrie, J. M. (1913). Przygody Piotrusia Pana (Z. Rogoszówna, tłum.). Wydawnictwo J. Mortkowicza. (wyd. oryg. 1906).

Clute, J. (1999). Urban fantasy. W: J. Clute, J. Grant (red.), The encyclopedia of fantasy (wyd. 2, s. 975-976). St. Martin's Griffin.

Dunin-Wąsowicz, P. (2010). Warszawa fantastyczna. Raster.

Ekman, S. (2018). Urban fantasy - literatura Niewidocznego (M. Wąsowicz, tłum.). Creatio Fantastica, 58(1), 7-27. https://doi.org/10.5281/zenodo.1419517. (wyd. oryg. 2016).

Fantastyka miejska. (2018). Creatio Fantastica, 58(1).

Gaiman, N. (2001). Nigdziebądź. Mag. (wyd. oryg. 1996).

Kosik, R. (2005). Felix, Net i Nika oraz Teoretycznie Możliwa Katastrofa. Powergraph.

Kosik, R. (2009). Felix, Net i Nika oraz Pułapka Nieśmiertelności. Powergraph. (wyd. oryg. 2007).

Kostecka W. (2014). Baśń postmodernistyczna: przeobrażenia gatunku. Intertekstualne gry z tradycja literacka. Wydawnict wo SBP.

Kostecka, W. (2016). (Po)nowoczesne przestrzenie popkultury. Studium przypadku: Omega Marcina Szczygielskiego. W: W. Kostecka, M. Skowera (red.), Geografia krain zmyślonych. Wokół kategorii miejsca i przestrzeni w literaturze dziecięcej, młodzieżowej i fantastycznej (s. 337-350). Wydawnictwo SBP.

Kubale, A. (1984). Dziecko romantyczne. Szkice o literaturze. Zakład Narodowy im. Ossolińskich, Wydawnictwo PAN.

Kulczycka-Saloni, J., Ihnatowicz, E. (red.). (1993). Warszawa pozytywistów. ILP UW.

Lorens, P. (2014). Tkanka miejska. W: P. Lorens, J. Martyniuk-Pęczek (red.). Wprowadzenie do projektowania urbanistycznego. Politechnika Gdańska.

Maj, K. M. (2918). Fantastyczna geopoetyka. Creatio Fantastica, 58(1), 127-134.

Międzyrzecki, A. (1965). Na przykład Ogród Saski. Ruch.

Mik, A. (2016). Miasto prawdziwe, miasto zmyślone. Transformacje Londynu w fantastyce dziecięcej i młodzieżowej. W: W. Kostecka, M. Skowera (red.), Geografia krain zmyślonych. Wokót kategorii miejsca i przestrzeni w literaturze dziecięcej, młodzieżowej i fantastycznej (s. 99-121). Wydawnictwo SBP.

Niewieczerzał, M. (2019). Stare i nowe miasto. Przyszłość bohaterów warszawskich legend. Literatura Ludowa, 68(1), 32-39. https://doi.org/10.12775/LL.1.2019.003. 
Oppman, A. (Or-Ot). (1945). Legendy warszawskie. Wydawnictwo E. Kuthana. (wyd. oryg. 1925).

Orbitowski, Ł., Urbaniuk, J. (2008). Przyśniła mi się wisząca platforma [wywiad z Rafałem Kosikiem]. Lampa, 12, 16-19.

Papuzińska, J. (1972). A gdzie ja się, biedniuteńki, podzieję?. Nasza Księgarnia.

Pastuszka, T. (2009). Legenda o Powstaniu. W: J. Ołdakowski (koncepcja), Powstanie ' 44 w komiksie. Antologia prac konkursowych. Egmont, Muzeum Powstania Warszawskiego.

Prus, B. (1890). Lalka. Gebethner i Wolff.

Rabska, Z. (1920a). Choinka Marcysi. W: Tajemnice Eazienek. Księgarnia Św. Wojciecha.

Rabska, Z. (1920b). Sny Wiesi. W: Tajemnice Łazienek. Księgarnia Św. Wojciecha.

Rabska, Z. (1920c). Tajemnice Łazienek. Księgarnia Św. Wojciecha.

Rabska, Z. (1957). Ania w Łazienkach. Czytelnik.

Reymont, W. (1899). Ziemia Obiecana. Gebethner i Wolff.

Rudniańska, J. (2007). Kotka Brygidy. Pierwsze.

Rybicka, E. (2003). Modernizowanie miasta. Zarys problematyki urbanistycznej w nowoczesnej literaturze polskiej. TAiWPN Universitas.

Rybicka, E. (2014). Geopoetyka. Przestrzeń i miejsce we wspótczesnych teoriach i praktykach literackich. TAiWPN Universitas.

Rzepnikowska, I. (2016-2018). Boruta. W: V. Wróblewska (red.), Słownik polskiej bajki ludowej. Pobrane 10 stycznia 2021 z: https://bajka.umk.pl/slownik/lista-hasel/ haslo/?id=35.

Szczygielski, M. (2009). Omega. Latarnik.

Szczygielski, M. (2013). Arka czasu, czyli wielka ucieczka Rafała od kiedyś przez wtedy do teraz i wstecz. Stentor.

Szczygielski, M. (2016). Klątwa dziewiątych urodzin. Bajka.

Terlikowska, M. (1970). Malowana awantura. Ruch.

Tyrmand, L. (1955). Zły. Czytelnik.

Wróblewska, V. (2016). Od przestrzeni realnej do wyimaginowanej - Toruń w literaturze dla dzieci. W: W. Kostecka, M. Skowera (red.), Geografia krain zmyślonych. Wokót kategorii miejsca i przestrzeni w literaturze dziecięcej, młodzieżowej i fantastycznej (s. 79-98). Wydawnictwo SBP.

Wróblewski, M. (2010). Świat według Kosika. W: B. Olszewska, E. Łucka-Zając (red.), "Stare" $i$ „nowe" w literaturze dla dzieci i młodzieży (s. 337-345). Wydawnictwo UO. 